\title{
Short-Term Administration of Rifampin in the Prevention or Eradication of Infection Due to Foreign Bodies
}

\author{
K. Tshefu, W. Zimmerli, and F. A. Waldvogel
}

\author{
From the Infectious Disease Division, \\ Department of Medicine, University Hospital, \\ Geneva, Switzerland
}

\begin{abstract}
Short-term administration of rifampin was evaluated as a means of preventing or eradicating infection due to foreign bodies. Tissue cages were implanted into guinea pigs and subsequently infected with $10^{3}$ colony-forming units of Staphylococcus aureus Wood 46. Infection developed in all tissue cages. Rifampin was administered thereafter intraperitoneally at a dosage of $7.5 \mathrm{mg} / \mathrm{kg}$ every $12 \mathrm{hr}$ for $48 \mathrm{hr}$, and the tissue-cage fluid was monitored for possible development of infection by quantitative bacteriologic methods for 15 days. In all cases rifampin prevented or eradicated tissue-cage infection if treatment was initiated either $3 \mathrm{hr}$ before or $\leqslant 12 \mathrm{hr}$ after inoculation of microorganisms but was ineffective if initiated $>12 \mathrm{hr}$ after inoculation. In cases of failure of treatment, rifampin-resistant variants could be demonstrated. Rifampin seems to prevent or eradicate tissue-cage infection only if given early after bacterial inoculation.
\end{abstract}

The development of an infection in the vicinity of a foreign body or prosthetic material remains a major problem in orthopedic, cardiac, and general surgery [1-3] as well as in internal medicine [4]. Conceptually, three major groups of pathogenic factors could contribute, either singly or in combination, to the development of such infections. Altered virulence and/or surface modifications of the infecting organisms could protect them from host-dependent antibacterial systems or from antimicrobial agents; alternatively, the foreign or prosthetic surface per se could favor, either directly or indirectly, the propagation of the offending microorganism; finally, the host's natural defense mechanisms against pyogenic organisms might be altered in the vicinity of a foreign body. Preliminary experimental data that favor the latter two mechanisms have recently been presented $[5,6]$. Little is known about the microbiologic determinants of prosthetic infections; however, the efficacy of preventive, short-term antibiotic thera-

This work was supported in part by grant no. 3.836.79 from the Swiss Research Foundation.

Dr. K. Tshefu is the holder of a fellowship from the World Health Organization, Geneva, Switzerland. Dr. W. Zimmerli is the holder of a fellowship from the Swiss Research Foundation, Bern, Switzerland.

The authors thank Mrs. Anneliese Kahr and Mrs. Elisabeth Huggler for technical assistance and Miss Françoise Michaud for editing the manuscript.

Please address requests for reprints to Dr. F. A. Waldvogel, Infectious Disease Division, University Hospital, 1211 Geneva 4, Switzerland. py $[7,8]$, in contrast to the inefficacy of antibiotic therapy initiated after infection has developed, suggests a change in bacterial behavior during the establishment of foreign-body infection.

Since it is generally accepted that the consequences of infection in the vicinity of foreign material are disastrous, interest is growing in the establishment of guidelines for regimens of preventive antibiotic treatment either during insertion of prosthetic devices or during later septic manipulations. Because of the lack of an animal model, few solid data are available about optimal dosage, timing, and duration of such prevention programs and the choice of antibiotics.

In the present study we used an experimental model of foreign-body infection recently developed in our laboratory [6] to address these questions. In particular, we evaluated the efficacy of rifampin, an antibiotic with high antistaphylococcal activity and good cell membrane penetration [9-11], in preventing or eradicating foreignbody infection.

\section{Materials and Methods}

Experimental model. Sterile polytetrafluorethylene (Teflon $\left.{ }^{(}\right)$tissue cages constructed as previously described [6], with external and internal diameters of $10 \mathrm{~mm}$ and $8 \mathrm{~mm}$, respectively, and perforated by 130 regularly spaced holes were implanted under strictly aseptic conditions into the flanks of guinea pigs weighing $500-600 \mathrm{~g}$. 
Animals were used for experimental infections after the incision had healed completely and the metal clips had been removed, i.e., two or more weeks after surgery.

Collection and storage of tissue-cage fluid. Samples of tissue-cage fluid were obtained by percutaneous aspiration, which has been described previously for a similar model [12]. Thereafter, samples either were used directly for bacteriologic quantitation or were stored at $-70 \mathrm{C}$ for further determinations.

Microbiologic characteristics of the infecting strain. Aliquots of the same initial culture of Staphylococcus aureus Wood 46, stored at $-70 \mathrm{C}$, were used for all experiments. This strain was shown by the Kirby-Bauer method [13] to be sensitive to all common antibacterial agents tested, including penicillin, methicillin, erythromycin, tetracycline, and rifampin [14]. When submitted to a standard scheme for staphylococcal identification, the strain gave positive reactions for catalase production, plasma coagulase reaction, DNase activity, and mannitol fermentation [14].

Before inoculation into tissue cages, $S$. aureus Wood 46 was preincubated overnight in MuellerHinton broth, centrifuged, washed, and resuspended in $1.0 \mathrm{ml}$ of $0.85 \%$ saline; $0.2 \mathrm{ml}$ of this diluted suspension was injected into each tissue cage, resulting in an inoculum of $\sim 10^{3}$ organisms. Clumping of microorganisms was kept at a minimum under these preincubation conditions and was monitored regularly by microscopic evaluation.

Microorganisms isolated from infected tissue cages were checked for their identity with the initial, inoculated strain by the above-mentioned biochemical tests. Appropriate antibiotic susceptibility tests also were performed for confirmation of identity between the inoculated and the isolated microorganisms.

Microbiologic techniques, Rifampin assays were performed with a microbiologic method in which Sarcina lutea was used as the indicator strain and DST (diagnostic sensitivity) Oxoid, (Oxoid Ltd., Beckingham, England) with $3 \mathrm{ml}$ of $\mathrm{KH}_{2} \mathrm{PO}_{4}(1 M) / 100 \mathrm{ml}$ was used as the medium [15]. The assay was linear for concentrations of rifampin of $0.12 \mu \mathrm{g} / \mathrm{ml}-1.0 \mu \mathrm{g} / \mathrm{ml}$. Pure rifampin (Ciba-Geigy, Basel, Switzerland) was dissolved in N, N-dimethylformamide (Sigma, St. Louis, Mo.) at a concentration of $1 \mathrm{mg} / \mathrm{ml}$. Further dilutions were performed in PBS (Dulbecco's phosphate- buffered saline; Gibco-Bio-Cult., Glasgow, Scotland). This solution was used for the standard curves, which were established for each assay. Identical standard curves were obtained when PBS was partially substituted with $25 \%$ serum or $75 \%$ tissue-cage fluid.

Quantitative cultures of tissue-cage fluid were performed by plating $0.1 \mathrm{ml}$ on Mueller-Hinton agar, after making appropriate dilutions in sterile water, and incubating cultures for $48 \mathrm{hr}$ before performing colony counts. Absence of spontaneous contamination of tissue-cage fluids was confirmed before starting each experiment by culturing undiluted fluid on Mueller-Hinton agar. Finally, in some experiments tissue cages were excised under aseptic conditions and checked for the presence of microorganisms by rolling the cages over Mueller-Hinton agar plates and culturing the plates subsequently in Mueller-Hinton broth.

\section{Results}

Choice of initial inoculum and of rifampin regimen. In a first series of experiments, the rate of development of infections was quantitated by inoculating various numbers of $S$. aureus Wood 46 into the tissue cages and by evaluating bacterial multiplication as a function of time. As shown in figure 1 , infection of the tissue-cage fluid was achieved with initial inocula as small as $10^{2} \mathrm{cfu}$ and was readily demonstrable bacteriologically by $20 \mathrm{hr}$. With an inoculum of $\geqslant 10^{3} \mathrm{cfu}$, quantitation of bacterial counts at $22 \mathrm{hr}$ showed the presence of $\sim 10^{5}-10^{8}$ organisms $/ \mathrm{ml}$, most of them identified as single cocci by microscopic examination. When bacterial counts were measured after the first 24 $\mathrm{hr}$, they fluctuated considerably-probably because of bacterial clumping. Finally, control curves showed that bacterial growth in MuellerHinton broth or under in vitro conditions in tissue-cage fluid was more rapid than in the in vivo system. These results considered together suggested that $10^{3} \mathrm{cfu}$ of $S$. aureus Wood 46 was an adequate initial inoculum, that an observation period of $20 \mathrm{hr}$ was sufficient for the demonstration of an infection in the absence of antibiotics, and that fluid accumulating in tissue cages did not provide particularly favorable growth conditions for $S$. aureus Wood 46.

For evaluation of the efficacy of rifampin in ex- 


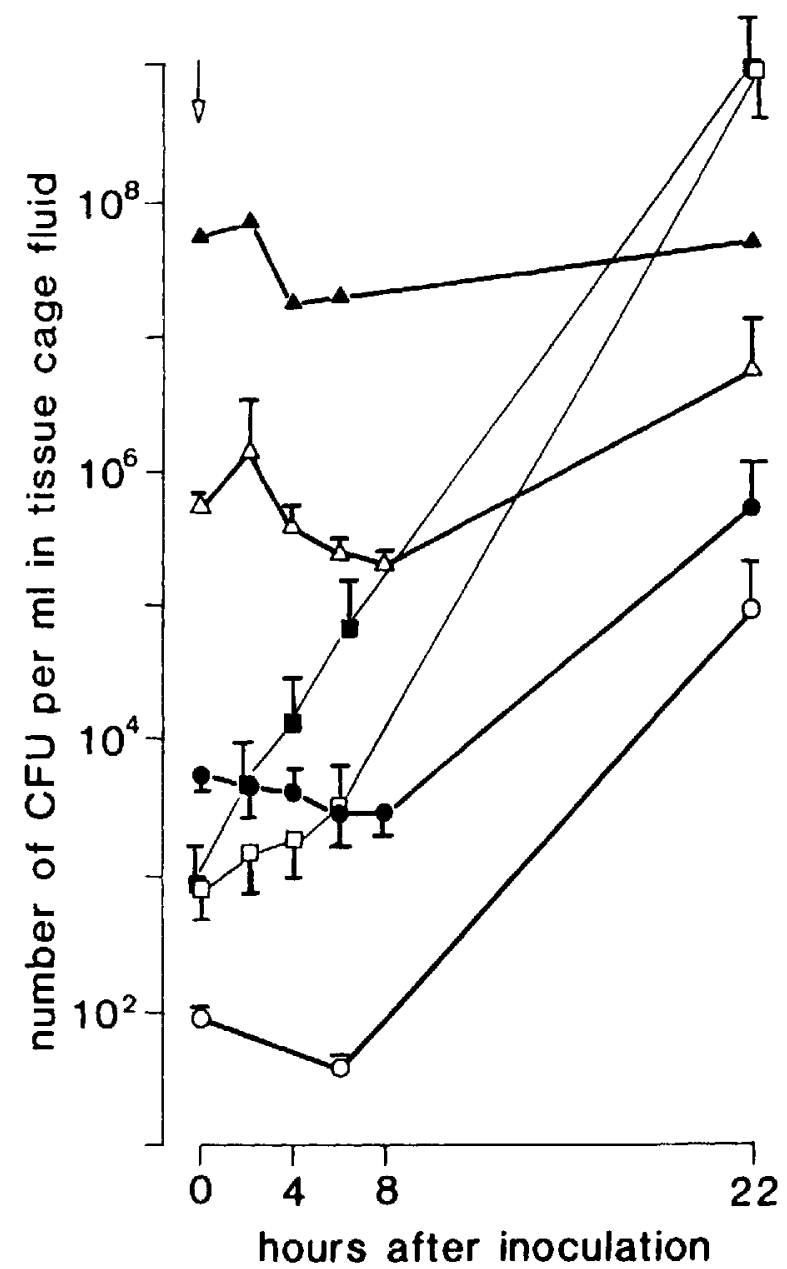

Figure 1. Growth curves of Staphylococcus aureus Wood 46 in tissue cages in vivo and control values of bacterial growth in either $100 \%$ tissue-cage fluid $(\square ; n=$ 3) or Mueller-Hinton broth ( $\square ; n=3$ ) in vitro. Indicated inocula of $S$. aureus were injected into tissue cages at time zero (arrow). Values are reported as the mean \pm SEM of the $\mathrm{cfu}$ at the indicated time intervals after experimental infection with the following initial inoculum: $\sim 10^{2} \mathrm{cfu}$ $(0-0 ; n=8), \sim 10^{4} \mathrm{cfu}(\longrightarrow ; n=4), \sim 10^{6}$ cfu ( $\left.\triangle \quad \Delta ; n=4), \sim 10^{8}(\Delta-\mathbf{\Delta}) ; n=2\right)$. perimental tissue-cage infections, an antibiotic regimen had to be chosen that gave concentrations of antibiotic in tissue-cage fluid exceeding the MIC and MBC for S. aureus Wood 46. The MIC at $18 \mathrm{hr}$ in Mueller-Hinton broth was $0.005 \mu \mathrm{g} / \mathrm{ml}$ with an initial inoculum of $10^{5} \mathrm{cfu}$. The MBC, which was defined as the antibiotic concentration leading to a killing of $99.9 \%$ at $24 \mathrm{hr}$, was 0.046 $\mu \mathrm{g} / \mathrm{ml}$; no skip-tube phenomenon was observed. When tests were made in Mueller-Hinton medium supplemented with $25 \%$ pooled guinea pig serum, $\mathrm{MIC}$ and MBC values were $0.023 \mu \mathrm{g} / \mathrm{ml}$ and 0.046 $\mu \mathrm{g} / \mathrm{ml}$, respectively. Several antibiotic regimens were examined for the purpose of obtaining levels of antibiotic in tissue-cage fluid exceeding the MIC and MBC during the entire treatment period. Figure 2 shows that with a regimen of $7.5 \mathrm{mg}$ of rifampin $/ \mathrm{kg}$ given ip every $12 \mathrm{hr}$, trough levels of rifampin at $24 \mathrm{hr}$ and $48 \mathrm{hr}$ after initation of therapy were $0.115 \pm 0.035$ and $0.15 \pm 0.027 \mu \mathrm{g} / \mathrm{ml}$, respectively, values exceeding the MIC for $S$. aureus Wood 46 by factors of 5 and 6.5 , respectively.

Partial prevention or eradication of infections of tissue-cage fluid with rifampin: emergence of rifampin-resistant mutants. Seven different treatment schedules (A-G; table 1) were evaluated; they differed by one parameter only-i.e., the time lag between the inoculation of the microorganisms and the initiation of therapy. This time lag varied from $-3 \mathrm{hr}$ (for treatment group A; antibiotic regimen started $3 \mathrm{hr}$ before inoculation) to $48 \mathrm{hr}$ (for group G; antibiotic regimen started $48 \mathrm{hr}$ after inoculation). Tissue-cage fluids of groups A-F were aspirated and cultured $24 \mathrm{hr}, 48$ $\mathrm{hr}$, six days, and 15 days after initiation of therapy.

In group $\mathrm{G}$ the establishment of infection was confirmed $24 \mathrm{hr}$ before and at the beginning of rif-

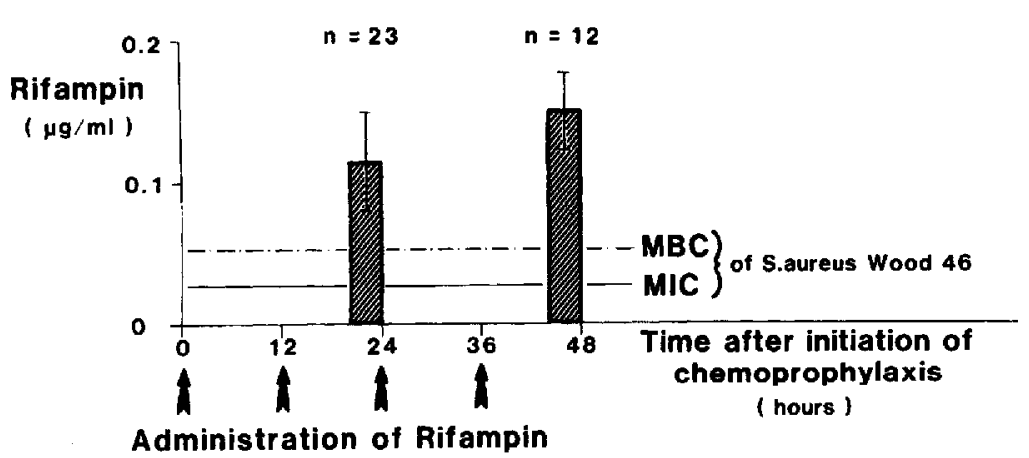

Figure 2. Trough level of rifampin $(\mu \mathrm{g} / \mathrm{ml})$ in tissue-cage fluid $24 \mathrm{hr}$ and $48 \mathrm{hr}$ after administration of $7.5 \mathrm{mg}$ of rifampin $/ \mathrm{kg}$ ip every $12 \mathrm{hr}$ for 48 $\mathrm{hr}$. The solid line represents the MIC and the dotted line, the MBC of the infecting strain, Staphylococcus aureus Wood 46. 
Table 1. Treatment regimens for guinea pigs with foreign-body infections.

\begin{tabular}{lcc}
\hline $\begin{array}{l}\text { Prophylaxis or } \\
\text { treatment group }\end{array}$ & $\begin{array}{c}\text { Rifampin administered } \\
\text { at indicated interval (hr) } \\
\text { before (-) or after }(+) \\
\text { inoculation }\end{array}$ & $\begin{array}{c}\text { No. of tissue } \\
\text { cages } \\
\text { inoculated* }\end{array}$ \\
\hline A & -3 & 7 \\
B & 0 & 8 \\
C & +3 & 10 \\
D & +6 & 8 \\
E & +12 & 8 \\
F & +24 & 8 \\
G & +48 & 4 \\
\hline
\end{tabular}

NOTE. Tissue-cage fluid was sampled for quantitative cultures at $24 \mathrm{hr}, 48 \mathrm{hr}$, six days, and 15 days after the onset of the antibiotic prophylaxis or therapy.

* Tissue cages were inoculated with $10^{3} \mathrm{cfu}$ of Staphylococcus aureus Wood 46. Dosage of rifampin was $7.5 \mathrm{mg} / \mathrm{kg}$ ip every $12 \mathrm{hr}$ for $48 \mathrm{hr}$.

ampin treatment. Further cultures of tissue-cage fluid were performed at $24 \mathrm{hr}$, six days, nine days, and 15 days after initiation of therapy. Results of these experiments are described in tables 1 and 2 . When rifampin was administered either before, during, or $12 \mathrm{hr}$ after inoculation of $S$. aureus Wood 46, tissue cages were invariably sterile when tested six days or 15 days after initiation of the 48-hr treatment regimen. Eradication of infection was achieved at the end of therapy, even in cases for which tissue-cage fluids were culture positive at $48 \mathrm{hr}$, i.e., contained up to $10^{3} \mathrm{cfu} / \mathrm{ml}$. If initiation of therapy was delayed beyond $12 \mathrm{hr}$ after inoculation, infection could not be eradicated; despite the fact that tissue-cage fluids were negative six days after initiation of the 48-hr therapy, eight of 11 were positive at 15 days, with bacterial counts ranging from $10^{2}$ to $10^{8} \mathrm{cfu} / \mathrm{ml}$. It is of interest that after administration of antibiotic infection in the tissue-cage fluid recurred slowly, requiring observation periods of up to 15 days for confirmation of all relapses. These results were in striking contrast with those obtained in the absence of the antibiotic, for which bacterial growth could consistently be demonstrated in tissue-cage fluid $12 \mathrm{hr}$ after inoculation.

Because of the delay in recurrence of infection, we investigated whether negative cultures actually reflected the inadequacy of the technique of aspirating tissue-cage fluid for collecting bacteria closely associated with the foreign body. Tissue cages with sterile fluid cultures were therefore excised 15 days after initiation of effective rifampin treatment and cultured according to the technique described in Materials and Methods; all cages were free of organisms. In one case of ineffective treatment-rifampin was started $48 \mathrm{hr}$ after inoculation of $S$. aureus (group G) - tissue-cage fluid was negative at 15 days, whereas the excised tissue cage showed growth with both techniques (table 2 and figure 3 ).

The time course of the recurrence of infection is depicted in more detail in figure 3 for four tissue cages in animals in which rifampin treatment was started $48 \mathrm{hr}$ after inoculation of bacteria. Bacterial counts decreased from initial values of 2.5 $\times 10^{4}-1.6 \times 10^{6} 48 \mathrm{hr}$ after inoculation to $<10 \mathrm{cfu}$

Table 2. Effect of time of initiation of rifampin regimen on protection against or eradication of foreign-body infection.

Treatment group, no. of hr before $(-)$ or after $(+)$ inoculation that rifampin regimen initiated*

A, -3

B, 0

$\mathrm{C},+3$

$\mathrm{D},+6$

$\mathrm{E},+12$

$\mathrm{F},+24$

$\mathrm{G},+48$
No. of tissue-cage fluids positive for infecting organism on indicated day after initiation of rifampin/no. inoculated ${ }^{\dagger}$

\begin{tabular}{llll}
\multicolumn{1}{c}{1} & \multicolumn{1}{c}{2} & \multicolumn{1}{c}{6} & \multicolumn{1}{c}{15} \\
\hline $0 / 7$ & $1 / 7\left(10^{1}-10^{2}\right)$ & $0 / 7$ & ND \\
$0 / 4$ & $0 / 4$ & $0 / 4$ & $0 / 4^{\ddagger}$ \\
$0 / 10$ & $0 / 10$ & $0 / 10$ & ND \\
$4 / 8\left(10^{1}-10^{3}\right)$ & $4 / 8\left(10^{1}-10^{3}\right)$ & $0 / 8$ & ND \\
$6 / 8\left(10^{1}-10^{3}\right)$ & $0 / 16$ & $0 / 16$ & $0 / 8^{\ddagger}$ \\
$5 / 8\left(10^{2}-10^{4}\right)$ & $11 / 15\left(10^{1}-10^{8}\right)$ & $0 / 15$ & $4 / 7\left(10^{8}\right)$ \\
$4 / 4\left(10^{3}-10^{5}\right)$ & ND & $0 / 4$ & $4 / 4\left(10^{1}-10^{5}\right)^{8}$ \\
\hline
\end{tabular}

* Tissue cages were inoculated with $10^{3} \mathrm{cfu}$ of Staphylococcus aureus Wood 46 . Dosage of rifampin was $7.5 \mathrm{mg} / \mathrm{kg} \mathrm{ip} \mathrm{every}$ $12 \mathrm{hr}$ for $48 \mathrm{hr}$.

$\dagger$ Numbers in parentheses are $\mathrm{cfu} / \mathrm{ml}$ of tissue-cage fluid. $\mathrm{ND}=$ not done.

All excised tissue cages also were culture negative.

$\S$ In one case only the tissue cage was culture positive. 


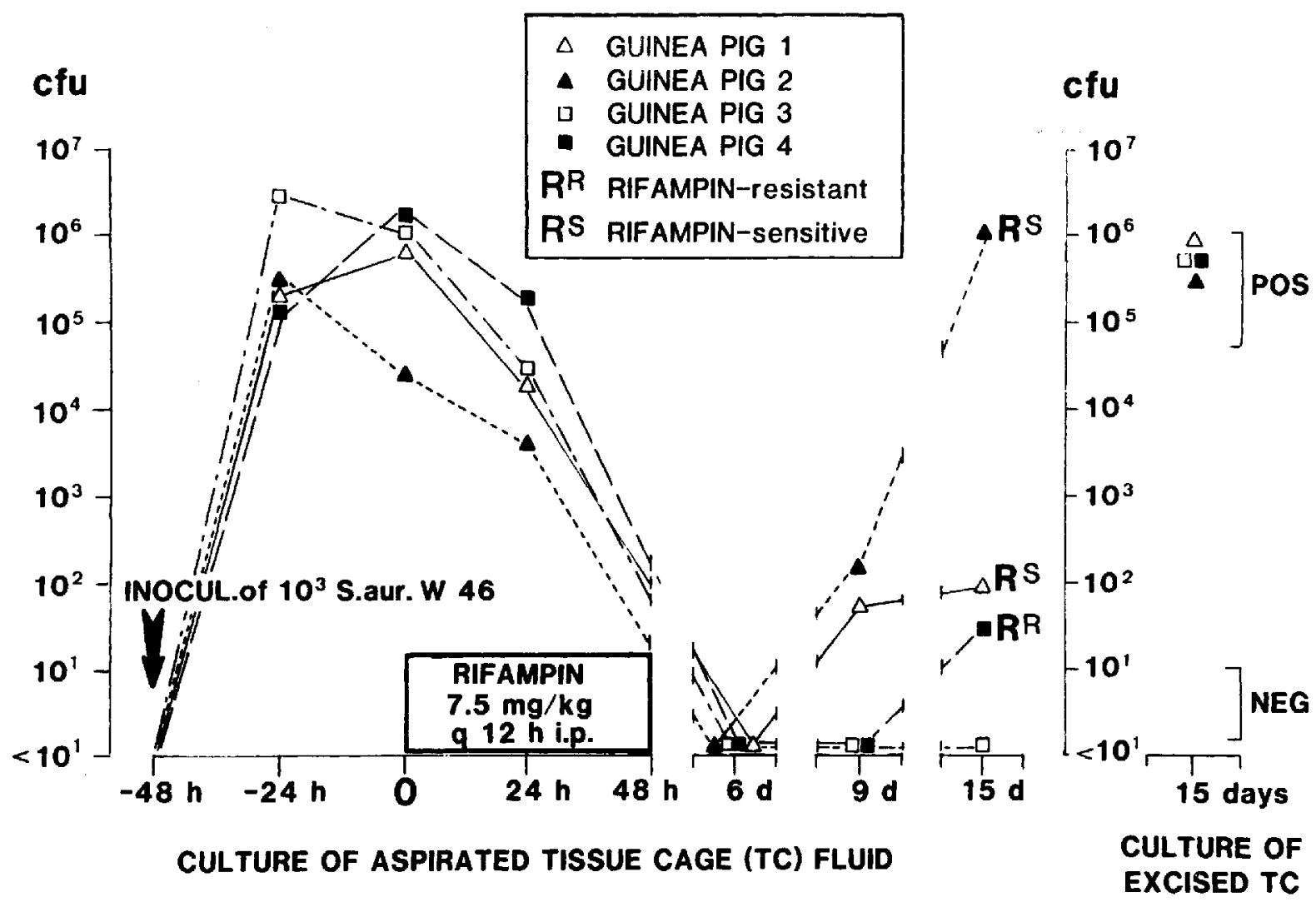

Figure 3. Number of cfu of Staphylococcus aureus Wood 46 in tissue-cage fluid in four guinea pigs treated according to treatment regimen $\mathrm{G}$ and susceptibility of isolates to rifampin at end of observation period. Time zero indicates initiation of therapy with $7.5 \mathrm{mg}$ of rifampin $/ \mathrm{kg}$ ip every $12 \mathrm{hr}$ for $48 \mathrm{hr}$. Tissue cages were excised 15 days after initiation of therapy and cultured in Mueller-Hinton broth (for details see Materials and Methods); all four cages were positive for $S$. aureus Wood 46 (at right).

six days after initiation of the 48-hr therapy regimen. Bacterial counts in tissue-cage fluid gradually increased at nine days for two of four cages and at 15 days for three of four cages. The fourth tissue-cage fluid was negative throughout the observation period, whereas all excised tissue cages were positive. Finally, one of four cultures obtained at the end of the observation period showed two types of $S$. aureus, one that remained sensitive to $0.023 \mu \mathrm{g}$ of rifampin $/ \mathrm{ml}$, the other that was resistant to $>31 \mu \mathrm{g}$ of rifampin $/ \mathrm{ml}$. Both types of $S$. aureus colonies were identical in all other biochemical characteristics and antibiotic sensitivities.

\section{Discussion}

Despite the abundant use of antibacterial agents for the prevention of postsurgical infections, there is no general consensus as to their indications, choice, timing, and duration of administration
[16]. This lack of adequate guidelines is of even greater concern for those infections that occur after insertion of prosthetic material, since such infections are associated with a particularly poor prognosis. Prosthetic valve endocarditis and osteomyelitis following reconstructive orthopedic surgery usually require the removal of the foreign material for cure $[1,17]$. It therefore seems particularly desirable to establish appropriate antibiotic regimens for the prevention or early eradication of these infections, which most often are due to staphylococci.

The paucity of clinical data regarding prosthetic infections and their prevention probably reflects the difficulty in setting up adequate controlled studies, which require unambiguous criteria for the assessment of infection, accurate determinations of antibiotic concentrations in the neighborhood of the prosthesis, and well-defined end points for both duration of antibiotic therapy and 
the consecutive observation periods. We believe that the present experimental model, which has previously been used for pharmacokinetic studies $[12,18]$ and for establishment of successful growth of fastidious microorganisms [19], can be applied to answer some of these questions.

Our results show that administration of rifampin at a dosage regimen that achieves bactericidal concentrations in tissue-cage fluid for at least 48 $\mathrm{hr}$ prevented the development of foreign-body infection, provided that antibacterial treatment was started $\leqslant 12 \mathrm{hr}$ after inoculation of a rifampinsensitive strain of $S$. aureus. If the time lag between the inoculation of the pathogen and the initiation of therapy was $>12 \mathrm{hr}$, however, infection invariably developed despite treatment with rifampin for $48 \mathrm{hr}$, and occasionally rifampinresistant variants emerged. Finally, whereas tissue-cage infections developed in $<20 \mathrm{hr}$ in the absence of rifampin administration, more than six days were required for them to be detected microbiologically after unsuccessful rifampin therapy. This observation could be explained by a prolonged postantibiotic effect, as described for other antibacterial agents [20]. Alternatively, persistent bacteria may have remained adherent to the foreign body and protected from the antibiotic effect, contaminating the tissue-cage fluid at a later stage. Finally, some rifampin-resistant mutants of $S$. aureus Wood 46 produce less catalase and are less pathogenic than the wild strain in mice [21]. In our experience, however, both the resistant and the sensitive variants were equally susceptible to the bactericidal action of peritoneal granulocytes. Present work in our laboratory is aimed at the further evaluation of these possibilities.

The experimental system presented in this communication requires two comments. First, despite others' claims to having encountered difficulty in performing bactericidal assays with $S$. aureus Wood 46 [22], we did not encounter any such problems; the MIC and MBC were in the range of those given by Mandell for the same organism [10] and by others for various strains of $S$. aureus [9, 23]. Second, we occasionally observed delayed infection of tissue-cage fluid or infection limited to the tissue cage after ineffective rifampin treatment. These observations could suggest that in the case of "effective" rifampin treatment cultures of tissue-cage fluid were falsely negative because either the observation period was too short or microorganisms persisted on the Teflon surface. These possibilities were ruled out by control experiments involving the excision of tissue cages with culture-negative fluid and the demonstration of the sterility of the cages by adequate culture techniques.

The incomplete protection or eradication of infection demonstrated with short-term administration of rifampin in our experimental model is in keeping with similar data obtained with experimental endocarditis [24], osteomyelitis [25], and peritonitis [26]. In all four conditions, high numbers of bacteria were exposed to rifampin, either because of a prolonged delay between inoculation and initiation of antibacterial therapy (our study and $[24,25])$ or because of a high initial inoculum [26]. It is therefore not surprising that in all four experimental conditions, emergence of rifampinresistant variants was demonstrated. This observation obtained in different experimental models might well set a limit on the use of rifampin as a single therapeutic agent-but not necessarily as a prophylactic drug - since initial inocula probably are low in clinical postsurgical infections.

\section{References}

1. Waldvogel FA, Vasey H. Osteomyelitis: the past decade. N Engl J Med 1980;303:360-70

2. Kloster FE. Complications of artificial heart valves. JAMA 1979;241:2201-3

3. Georgiade NG, King EH, Harris WA, Tenery JH, Schlech BA. Effect of three proteinaceous foreign materials on infected and subinfected wound models. Surgery 1975; 77:569-76

4. Waldvogel FA. Infections et prothèses. In: Bastin $R$, ed. Les infections bactériennes d'actualité. Masson, Paris: 1977:103-20

5. Peters G, Locci R, Pulverer G. Microbial colonization of prosthetic devices. II. Scanning electron microscopy of naturally infected intravenous catheters. Zentralbl Bakteriol [B] 1981;173:293-9

6. Zimmerli W, Waldvogel FA, Vaudaux P, Nydegger UE. Pathogenesis of foreign body infection: description and characteristics of an animal model. J Infect Dis 1982; 146:487-97

7. Pollard JP, Hughes SPF, Scott JE, Evans MJ, Benson MKD. Antibiotic prophylaxis in total hip replacement. Br Med J 1979;1:707-9

8. Kaiser AB, Clayson KR, Mulherin $\mathrm{JL}_{\mathrm{J}}$, Roach AC, Allen TR, Edwards WH, Dale WA. Antibiotic prophylaxis in vascular surgery. Ann Surg 1978;188:283-9

9. Sabath LD, Garner C, Wilcox C, Finland M. Susceptibility of Staphylococcus aureus and Staphylococcus epidermidis to 65 antibiotics. Antimicrob Agents Chemother 1976;9:962-9 
10. Mandell GL, Vest TK. Killing of intraleukocytic Staphylococcus aureus by rifampin: in vitro and in vivo studies. J Infect Dis 1972;125:486-90

11. Solberg CO, Hellum KB. Protection of phagocytosed bacteria against antimicrobial agents. Scand J Infect Dis [Suppl] 1978;14:246-50

12. Chisholm GD. The tissue cage model in the distribution of antibacterial agents. Scand J Infect Dis [Suppl] 1978; 14:118-24

13. Bauer AW, Kirby WMM, Sherris JC, Turck M. Antibiotic susceptibility testing by a standardized disk method. Am J Clin Pathol 1966;45:493-6

14. Lennette EH, Spaulding EH, Truant JP, eds. Manual of clinical microbiology. 2nd ed. Washington DC: American Society for Microbiology, 1974

15. Williams JD, Leung T. Rifamycins. In: Reeves DS, Phillips I, Williams JD, Wise R, eds. Laboratory methods in antimicrobial chemotherapy. Edinburgh: Churchill Livingstone, 1978:239-43

16. Shapiro M, Townsend TR, Rosner B, Kass EH. Use of antimicrobial drugs in general hospitals. Patterns of prophylaxis N Engl J Med 1979;301:351-5

17. Karchmer AW, Stinson EB. The role of surgery in infective endocarditis. In: Remington JS, Swartz MN, eds. Current clinical topics in infectious diseases. New York; McGraw-Hill, 1980:124-57

18. Kaye D, Parsons JN, Carrizosa J, Kobasa WD. Treatment of experimental Staphylococcus aureus abscesses: comparison of cefazolin, cephalothin, cefoxitin, and cefamandole. Antimicrob Agents Chemother 1979;15:200-3
19. Tight RR, Perkins RL. Treponema pallidum infection in subcutaneous polyethylene chambers in rabbits. Infect Immun 1976;13:1606-12

20. Bundtzen RW, Gerber AU, Cohn DL, Craig WA. Postantibiotic suppression of bacterial growth. Rev Infect Dis 1981;3:28-37

21. Mandell GL. Catalase, superoxide dismutase, and virulence of Staphylococcus aureus. In vitro and in vivo studies with emphasis on staphylococcal-leukocyte interaction. J Clin Invest 1975;55:561-6

22. Zinner SH, Husson M, Klastersky J. Effect of mixing on rifampin bactericidal activity against staphylococci. Antimicrob Agents Chemother 1981;20:267-9

23. Tuazon CU, Lin MYC, Sheagren JN. In vitro activity of rifampin alone and in combination with nafcillin and vancomycin against pathogenic strains of Staphylococcus aureus. Antimicrob Agents Chemother 1978;13: $759-61$

24. Sande MA, Johnson ML. Antimicrobial therapy of experimental endocarditis caused by Staphylococcus aureus. J Infect Dis 1975;131:367-75

25. Norden CW, Experimental osteomyelitis. IV. Therapeutic trials with rifampin alone and in combination with gentamicin, sisomicin, and cephalothin. J Infect Dis 1975;132:493-9

26. Mandell GL, Moorman DR. Treatment of experimental staphylococcal infections: effect of rifampin alone and in combination on development of rifampin resistance. Antimicrob Agents Chemother 1980;17:658-62 